\title{
Comparative Study of Trend of Suicidal Cases in the Lockdown Period during Severe Phase of First Wave of COVID-19 with Those in Second Wave in Patna among Dead Bodies Brought for Autopsy at Nalanda Medical College, Patna - A Retrospective Study
}

\author{
Rajiv Ranjan Das ${ }^{1}$, Kumar Saurav ${ }^{2}$, Radha Raman Singh ${ }^{3}$ \\ ${ }^{1}$ Associate Professor, Department of F.M.T, Nalanda Medical College, Patna, India. \\ ${ }^{2}$ Tutor, Department of F.M.T, Nalanda Medical College, Patna, India. \\ ${ }^{3}$ Associate Professor, Department of F.M.T, Nalanda Medical College, Patna, India.
}

Corresponding Author: Kumar Saurav

\begin{abstract}
Introduction: There is hardly a person in the world who is not affected by the fearsome covid19 pandemic either physically, psychologically and socio-economically. It has caused extreme mental stress to not only those infected but also those who had to remain indoors for prolonged period due to lockdown. The second wave in 2021 was deadlier with many casualties though there was no pan INDIA lockdown this time.
\end{abstract}

Aims and Objectives: 1) To study and compare all confirmed suicidal deaths in the first lockdown period upto its severe period (upto June 2020) with suicidal cases during the second phase of COVID-19, from March to June 2021 approximately.

2) Demographic analysis of suicidal cases with determinants like incidence, sex, \& age wise distribution, mode of suicide, any specific causes etc, will be studied \& evaluated for any perceptible change between the severe phases of first \& second waves

Materials and Methods: It is retrospective, record review analytical and comparative study based on postmortem examination reports of all cases conducted by all doctors of department of FMT, Nalanda Medical College, Patna who did autopsy during both periods of study together with study of all police inquests, requisitions(challans), sent by the police investigating officers of concerned cases.

Study period- a) 25th march 2020 to June 2020 (lockdown phase). b) March 2021 to June 2021

Results: Total number of suicides was more in Lockdown period of the First wave (10.88\%) than in the in the 2nd phase in 2021(9.87\%). In the First phase the cases of hanging were $75 \%$ \& due to poisoning $25 \%$. But in the 2nd phase hanging accounted for the $62.5 \%$, poisoning $31.25 \%$ \& Drowning 6.25\%

Conclusions: Lockdown had more impact on the mental health of a person in Covid than the actual severity of the disease as the number of suicides decreased in the 2nd phase though it was more severe. Financial concerns \& perils of confined life added to the fear of the unknown disease in lockdown \& in the second phase people were more prepared mentally \& financially to combat the disease.

Keywords: covid, lockdown, suicide, hanging, autopsy

\section{INTRODUCTION}

Almost, everyone in the world is affected by COVID19 pandemic, either physically or psychologically or socioeconomically. Initially called Novel corona virus, later it was popularly called COVID19 virus \& now it is officially 
Rajiv Ranjan Das et.al. Comparative study of trend of suicidal cases in the lockdown period during severe phase of first wave of COVID-19 with those in Second wave in Patna among dead bodies brought for autopsy at Nalanda Medical College, Patna - A retrospective study.

named SARS COV-2 (Severe Acute respiratory syndrome corona virus-2).[1]

Corona virus is basically a RNA virus causing influenza like symptoms in most of the cases, with varying severity from mild in most cases to severe with rapidly dipping oxygen saturation \&permanent changes in lungs. Severe cases often lead to multi organ failure \& subsequent death. Thus, the fear and psychosis associated with it is very much, often leading to irritability \& depression.[2]

Covid was first reported from Wuhan institute of Virology in China on 31st December 2019.[3] The infection is supposed to be transmitted by bats \& similar mammals. However, questions about leakage of virus from Wuhan laboratory, accidentally and knowingly, have been raised. WHO has also sent a group of scientists to unearth the origin of this dreaded virus \& they could not find any clinching evidence to suggest human instigated leakage of the virus, though they have not completely ruled out such a possibility, if any.[4]

In India the virus started spreading in March 2020 through air, though the first case was detected on 30th January 2020.[5] Thus the central government announced preparatory JANTA CURFEW on 22nd March 2020, followed by pan India lockdown from night of 24th March 2020.[6] Lockdown means all residents were asked to remain indoors except the persons dealing with essential services. The idea was to break the chain of transmission. However, besides its desirous effect, lockdown also led to unprecedented exodus of labourers \& migrants from states of their jobs to their homes. This caused great physical and mental turmoil with insurmountable financial hardships. The lockdown was extended phase wise as cases soared all over India followed by unlocks in which restrictions were gradually eased. Nationwide lockdown was imposed in four phases from 25th march 2020 to 31st May 2020. Unlock commenced from 1st June 2020 in phases.[7]
The peak of cases in first wave was till September 2020 with more severe cases till June after which unlock commenced. Then, the cases steadily dropped till march 2021 when the so called 2nd wave started. So, the stressful conditions of all persons during lockdown \& early unlock phases due to various physical, mental, \& socioeconomic challenges, reportedly led to increase in Depression \& suicides among the victims \& other trapped in prolonged lockdown. There was two prolonged problem, Covid scare while going out \& lockdown blues when confined to your house. Plummeting income \& frequent skirmishes among family members compounded the problem. These factors led to increase in depressive features in people, often leading to suicide or attempt to suicide. As the cases gradually went down after September, the stress also became lesser till the advent of the dreaded second wave from roughly from march 2021 onwards.[8] From March 2021 onwards the dreaded second wave started which took the world unawares. No one expected such severity \& there was gross underpreparedness in Oxygen supply, Hospital beds, medicines \& Vaccination. This, together with, rapid mutant strains led to significant upsurge in morality, as well as morbidity, till June 2021 after which the decline in cases \& enhanced vaccination started.

\section{AIMS AND OBJECTIVES:}

1) To study and compare all confirmed suicidal deaths in the first lockdown period from late March 2020 upto its severe peak period (June 2020), with suicidal cases during the severe second phase/wave from March 2021 to June 2021

2) Demographic analysis of suicidal cases with determinants like incidence, sex, \& age wise distribution, mode of suicide, any specific causes etc, will be studied \& evaluated for any perceptible change in suicidal deaths in both waves. 
Rajiv Ranjan Das et.al. Comparative study of trend of suicidal cases in the lockdown period during severe phase of first wave of COVID-19 with those in Second wave in Patna among dead bodies brought for autopsy at Nalanda Medical College, Patna - A retrospective study.

\section{MATERIAL AND METHODS}

Study design and method- It is retrospective, record review analytical and comparative study based on postmortem examination reports of all cases conducted by all doctors of department of FMT, Nalanda Medical College, Patna who did autopsy during both periods/waves of covid, together with study of all police inquests, requisitions(challans), sent by the police investigating officers of concerned cases.

Study site- The study will be carried in the department of FMT, Nalanda Medical College, Patna, Bihar, India. It is a tertiary level health care \& teaching centre situated in Patna, the capital of Bihar.

Study objectives- All postmortem cases of alleged suicides coming to Nalanda Medical College \& Hospital, Patna which have been confirmed as suicides. It is a retrospective study \& record review; the relatives of victims were not involved.

Study period- a) 25th march 2020 to September 2020 (lockdown phase). b) March 2021 to June 2021 (Second phase)

\section{Statistical analysis}

Statistical analysis was done by Epiinfo statistical tool. The result were calculated under standard demographic determinants. Qualitative data is presented as percentage .

\section{RESULT}

Period of study- It should be made clear that second wave was supposed to be from 1st March 2021 to end of June 2021, as it was the period with more severity \& maximum casualties. This was compared with Same period of 2020 as it was the period of first phase lockdown, thus, maximum severity of first phase.

It was comparative retrospective case review study. The determinants taken up and dealt with are: a) Total number of cases (all) that is total number of autopsies conducted during the periods under study in the mortuary of department of FMT, Nalanda Medical College, Patna.

b) Total number of alleged and confirmed suicidal cases.

c) mode of suicide.

d) sex differentiation.

e) age below 30 and above 30 years.

f) rural-urban divide, if possible, to know.

g) marital status.

h) socio-economic status.

i) seasonal variation.

Comparative charts were prepared between lockdown period (25th March 2020 to September 2020) \& Severe second phase (1st March 2021 to June 2021).

Table1. shows the percentage of suicidal death

\begin{tabular}{|l|l|l|l|}
\hline $\begin{array}{l}\text { Period of } \\
\text { study }\end{array}$ & $\begin{array}{l}\text { Total number } \\
\text { of autopsies }\end{array}$ & $\begin{array}{l}\text { Total number of } \\
\text { suicidal deaths }\end{array}$ & Percentage \\
\hline 1st phase & 147 & 16 & $10.88 \%$ \\
\hline 2nd phase & 162 & 16 & $9.87 \%$ \\
\hline
\end{tabular}

Table 2. Indicates mode of suicide

\begin{tabular}{|l|l|l|}
\hline $\begin{array}{l}\text { Period of } \\
\text { study }\end{array}$ & $\begin{array}{l}\text { Mode of suicide } \\
\text { (percentage) }\end{array}$ & \\
\hline & hanging & poisoning \\
\hline 1st phase & $12(75 \%)$ & $04(25 \%)$ \\
\hline 2nd phase & $10(62.5 \%)$ & $\begin{array}{l}05(31.25 \%) \text { \& Drowning } \\
01(6.25 \%)\end{array}$ \\
\hline
\end{tabular}

Table3. Sex distribution of victims

\begin{tabular}{|c|c|c|}
\hline Period of study & Male(percentage) & Female(percentage) \\
\hline 1st phase & $07(43.75 \%)$ & $09(56.25 \%)$ \\
\hline 2nd phase & $03(18.75 \%)$ & $13(81.25 \%)$ \\
\hline
\end{tabular}

Table 4. Age distribution of cases

\begin{tabular}{|l|l|l|}
\multicolumn{4}{c}{ Table 4. Age distribution of cases } \\
\hline $\begin{array}{l}\text { Period of } \\
\text { study }\end{array}$ & $\begin{array}{l}\text { Below 30 years } \\
\text { (percentage) }\end{array}$ & $\begin{array}{l}\text { Above 30 years } \\
\text { (percentage) }\end{array}$ \\
\hline 1st phase & $10(62.5 \%)$ & $06(37.25 \%)$ \\
\hline 2nd phase & $12(75 \%)$ & $04(25 \%)$ \\
\hline
\end{tabular}

Table 5. Marital status of victims

\begin{tabular}{|c|c|c|}
\hline $\begin{array}{l}\text { Period of } \\
\text { study }\end{array}$ & Married(percentage) & Unmarried(percentage) \\
\hline 1st phase & $10(62.5 \%)$ & $06(37.5 \%)$ \\
\hline 2nd phase & $07(43.75 \%)$ & $09(56.25 \%)$ \\
\hline
\end{tabular}

Table 6. Socio-economic status of victims

\begin{tabular}{|l|l|l|}
\hline Period of study & low(percentage) & average(percentage) \\
\hline 1st phase & $07(43.75 \%)$ & $09(56.25 \%)$ \\
\hline 2nd phase & $06(37.5 \%)$ & $10(62.5 \%)$ \\
\hline
\end{tabular}

Table 7. Seasonal variation in cases

\begin{tabular}{|l|l|l|l|l|}
\hline Period of study & Seasonal variation & & & \\
\hline & winter(percentage) & rainy(percentage) & spring(percentage) & summer(percentage) \\
\hline 1st phase & $0(0 \%)$ & $0(0 \%)$ & $07(43.75 \%)$ & $09(56.25 \%)$ \\
\hline 2nd phase & $0(0 \%)$ & $0(0 \%)$ & $03(18.75 \%)$ & $13(81.25 \%)$ \\
\hline
\end{tabular}


Rajiv Ranjan Das et.al. Comparative study of trend of suicidal cases in the lockdown period during severe phase of first wave of COVID-19 with those in Second wave in Patna among dead bodies brought for autopsy at Nalanda Medical College, Patna - A retrospective study.

\section{DISCUSSION}

Both the stages of Covid were real torrid experience for most of us. In the first phase, lockdown was imposed which helped in slowing down the spread of the virus. However, besides the obvious and now, well known physical problem, covid also resulted in insurmountable mental and economic problem in the masses. The fear of the unknown enemy with no definitive treatment, together with being confirmed indoors for the prolonged period led to many psycho-somatic issues especially in co-morbids who are more vulnerable. It is said that two utensils together always make a noise, similarly prolong stay of the spouses at home led to increase in marital discords. Economic stress due to loss of jobs, exodus of families, high cost of covid treatment, made the situation worse. Furthermore, news of death of near and dear ones, compounded the pall of groom. All these factors led to increase in cases of depressive features in person. Unfortunately, some of them who were emotionally labile cracked in these trying circumstances and committed or tried to commit suicide. Sen CS, Stuckler D (2008) also shows that the economic consequences of the pandemic are likely to lead to an increase in suicides as shown during past economic crises.

So, my purpose of study was to know about such aforesaid cases and make an in depth study on the impact of covid leading to suicide cases. Then, we compared the data with that of much more dreaded second phase to know about the impact of severity on our minds \& also whether the lack of lockdown \& increased severity of covid had any perceptible change in suicidal data in second phase. On comparing the two data, it was found that some factors went on expected lines with minor deviations whereas some of the deviations seen in other factors were wider and eye opening.

Total number of Autopsy cases in lockdown period of first wave was 147 but more autopsies were conducted in the same period of second wave was 162 (more) as there was no lockdown this time with obvious more movement of people.

[9] Total number of suicides were same in both phases \& this indicated that severity had less bearing on Suicide than lockdown. The Centre for Monitoring Indian Economy estimated that 27 million young people between the ages of 20-30 years lost their jobs in April 2020 during the lockdown [10]. It is also estimated that nearly 100 million Indian jobs are at risk in the coming months [11]. While modelling studies have predicted significant increases in suicides and attempted suicides in other countries in the coming years as unemployment increases.

[12] However, as we discussed the methods/modes of suicide there were important revelations. In the pre-lockdown phase, as in my earlier study, the cases of hanging were $66.66 \%$ but due to poisoning $33.34 \%$. But, as in my current study in the lockdown phase, hanging accounted for the $75 \%$ and poisoning just $25 \%$. In the second phase Hanging accounted for $62.5 \%$ \& poisoning $31.25 \%$. More, hanging in lockdown was due to the fact that in the lockdown phase, as shops were closed and vehicular traffic was restricted, so it was not possible for victims to procure poisonous substances. Thus, hanging was the preferred mode of suicide. [13] Other methods of suicide like self immolation, fall from heights, firearm, drowning etc were not found in this retrospective case study but for one case of Drowning in the second phase.

Aradhana Singh, C. L. Nawal, H. L. Saini et.al(2012) done a retrospective observational study of poisoning and hanging cases during lockdown as a marker of emotional tide of COVID-19 pandemic in a tertiary care center in North-western India and found that pre-lockdown and lockdown might have equal number of hanging cases during the study period, but percentage wise there is a definite rise in the hanging cases during lockdown, that is, $8 \%$ of the total MLC patients, while it was 5\% during prelockdown $(\mathrm{p}=0.409)$. Hanging cases during pre-lockdown period constitute around 
Rajiv Ranjan Das et.al. Comparative study of trend of suicidal cases in the lockdown period during severe phase of first wave of COVID-19 with those in Second wave in Patna among dead bodies brought for autopsy at Nalanda Medical College, Patna - A retrospective study.

$0.12 \%$ which rose to $0.21 \%$ during lockdown. In poisoning cases also the number was $2.5 \%$ during pre-lockdown period and $6.5 \%$ during lockdown period. Second phase, though more in severity or mortality, had lesser bearing on suicides as people were more prepared physically, mentally \& economically. Sadly, Authorities were not prepared leading to more deaths in second phase.[14]

Sex differentiation

data, surprisingly, showed significant deviation. It was surprising to note that more persons of lower age group (below 30 years) committed suicide in both study group. As elderly and co-morbid were more vulnerable to covid, this data was against the popular perception. More suicidal cases in youngsters can also be attributed to uncertainty in exam schedule due to covid. Age group 30 years was selected as cut off as beyond 30 years is the active, professional period of life with retirement generally pegged at 60 years. Hence pre 30 and past 30 victims were studied. Mamun MA, Griffths MD done a study in Bangladesh and found that overall, most vulnerable age group was of 16-30 years where maximum number of poisoning and hanging cases occurred. The least vulnerable age group was of over 50 years where total poisoning cases were 19 . Interestingly, there was no hanging cases in this age group.[15]

Marital status also showed accepted deviation and suicide, but in first phase more married (62.5\%) committed suicide than in second phase (43.75\%). This points to more marital discords due to lockdown in first phase. Socio-economic status of victims had minimal bearing showing that covid affected both, mighty \& poor alike. However, as in my previous study, in prelockdown phase, $61.12 \%$ belonged to low socio-economic group and $38.88 \%$ to average socio-economic group. This can be explained by the fact that covid affected less people of low socio-economic group and thus had lesser impact on their socioeconomic status. On the other hand, it mostly affected the middle class which had to face severe monetary loss due to lockdown, exodus of migrants and high cost of covid treatment. That is why there are no persons of high income group as they were more mentally and financially equipped to face the challenge. The plight of average socio-economic group, popularly called middle class in covid was sad but true.

Seasonal variation, in our opinion was more due to the period (season) of study than covid as there is no perceptible reason for increased covid deaths in a particular season.

\section{CONCLUSION}

Thus, we can say that there has been no significant during the first \& second phases of disease though, there was increase in suicidal cases during lockdown compared to pre-lockdown. However there has been an increase in hanging cases in the lockdown period and appreciable deviation in determinants such as age, socio-economic status and seasonal variation. All said and done I feel that this study, in its little way, has fulfilled the purpose of pinpointing at the differences between the two study groups vis-à-vis covid.

There is an urgency to realise the severity of this suicidal tendency. It is explicitly clear that suicide cases are more due to confinement of people, loss of jobs \& slowdown in economy due to strict lockdown as in First phase than the more severe second phase as the people were more prepared, vaccinated \& economically much stable to combat the challenge. However, to combat the problem due to emotional and psychological stress, a helpline number for the social and psychological support is needed. There should be sympathetic dedication towards the COVID-19 positive cases. Arrangement of good quality nutritive food for the hungry people, salary for the labourers/workers should be continued. This study will help us to be better prepared for such eventualities.

Lockdown must be needed based, preplanned and financial support to the 
Rajiv Ranjan Das et.al. Comparative study of trend of suicidal cases in the lockdown period during severe phase of first wave of COVID-19 with those in Second wave in Patna among dead bodies brought for autopsy at Nalanda Medical College, Patna - A retrospective study.

needy together with behavioural counselling should be undertaken in letter and spirit. Finally, we must assert that as covid is mutations fast \& various strains are emerging worldwide so, we urge everyone to take vaccination at the earliest possible opportunity to avoid more such lethal phases. Till then, everyone must follow the covid appropriate behavior, as shunning of the guard can prove detrimental. Unnecessary travel \& stringent check for All travellers especially foreign travellers is necessary as we can ill afford any other wave of COVID-19.

\section{Acknowledgement: None}

\section{Conflict of Interest: None}

\section{Source of Funding: None}

\section{Ethical Approval: Approved}

\section{REFERENCES}

1. WHO/2019nCoV/FAQ/Virus_origin/2020.1

2. Coronaviruses: an overview of their replication and pathogenesis. Fehr AR, Perlman S. Methods Mol Biol. 2015;1282:1-23. [PMC free article] [PubMed] [Google Scholar].

3. Clinical features of patients infected with 2019 novel coronavirus in Wuhan, China. Huang C, Wang Y, Li X, et al. Lancet. 2020;395:497-506. [PMC free article] [PubMed] [Google Scholar].

4. Gautam S, Hens L. SARS-CoV-2 pandemic in India: what might we expect? Environment, Development and Sustainability. 2020;22(5):3867-3869. doi: 10.1007/s10668-020-00739-5. [PMC free article] [PubMed] [CrossRef] [Google Scholar].

5. Lai C.-C., Shih T.-P., Ko W.-C., Tang H.-J., Hsueh P.-R. Severe acute respiratory syndrome coronavirus 2 (SARS-CoV-2) and corona virus disease-2019 (COVID-19): the epidemic and the challenges. Int $\mathrm{J}$ Antimicrob Agents. 2020;105924 [PMC free article] [PubMed] [Google Scholar].

6. Rawat M. Coronavirus in India: tracking country's first 50 COVID-19 cases; what numbers tell. India Today Magazine. 2020;1-10.

7. Pal A, Siddiqui D. Special Report: India's migrant workers fall through cracks in coronavirus lockdown-Reuters [Internet]. Available from: https://www.reuters.com/article/us-healthcoronavirus-india-migrants-spe/specialreport-indias-migrant-workers-fall-throughcracks-in-coronavirus-lockdownidUSKBN2230M3. Accessed 21 May 2020.

8. Bera B, Bhattacharjee S, Shit PK, Sengupta N, Saha S. Significant impacts of covid-19 lockdown on urban air pollution in Kolkata (India) and amelioration of environmental health. Environment, Development and Sustainability. 2020;2020:1-28. [PMC free article] [PubMed] [Google Scholar].

9. Sen CS, Stuckler D, Yip P, Gunnell D. Impact of global economic crisis on suicide: time trend study in 54 countries. BMJ. 2008;2013(347):7925.

10. Job loss due to coronavirus: 27 million youth in age group of 20-30 years lost jobs in April: CMIE - The Economic Times [Internet]. Available from: https://economictimes.indiatimes.com/news/ economy/indicators/unemployment-ratedips-to-23-97-data-from-cmieshows/articleshow/75689370.cms?from=md r. Accessed 25 May 2020.

11. Nayar L, Sood J, Kansara Y, Ahmad S. 100 Million and more Indian jobs are at risk after COVID-19 lockdown. Is your job safe? Outlook India. 2020.

12. Bhatia R. Predictions of Covid-19 related unemployment on suicide and excess mortality in the United States. medRxiv. 2020 May 18;2020.05.02.20089086.

13. Projected Deaths of Despair During COVID-19 well being trust [Internet]. Available from: https://wellbeingtrust.org/areasoffocus/policy-andadvocacy/reports/projected-deaths-ofdespair-during-covid-19/. Accessed 25 May 2020.

14. Aradhana Singh, C. L. Nawal, H. L. Saini et.al, A retrospective observational study of poisoning and hanging cases during lockdown as a marker of emotional tide of COVID-19 pandemic in a tertiary care center in Northwestern India. International Journal of Advances in Medicine 2021 
Rajiv Ranjan Das et.al. Comparative study of trend of suicidal cases in the lockdown period during severe phase of first wave of COVID-19 with those in Second wave in Patna among dead bodies brought for autopsy at Nalanda Medical College, Patna - A retrospective study.

Sep;8(9):1354-1359

http://www.ijmedicine.com.

15. Mamun MA, Griffths MD. First COVID-19 case in Bangladesh due to fear of COVID19 and xenophobia: possible suicide prevention strategies. Asian J Psychiatry. 2020;51:102073

16. Jain VK, Iyengar KP, Vaishya Raju. Difference between first wave and second wave of COVID-19 in India. Elsevier Ltd. May 2021.

17. Sarkar A, Chakrabarti AK, Dutta S. COVID-19 Infection in India: A Comparative Analysis of the Second Wave with the First Wave. September 2021. National Library of Medicine, Pubmed.

How to cite this article: Rajiv Ranjan Das, Kumar Saurav, Radha Raman Singh. Comparative study of trend of suicidal cases in the lockdown period during severe phase of first wave of COVID-19 with those in Second wave in Patna among dead bodies brought for autopsy at Nalanda Medical College, Patna - a retrospective study. International Journal of Research and Review. 2021; 8(12): 431-437. DOI: https://doi.org/10.52403/ijrr.20211253 